\title{
PENDAYAGUNAAN SUMBER DAYA GENETIK RUMPUT LAUT SEBAGAI SUMBER ENERGI ALTERNATIF DI MASA DEPAN
}

\author{
Nofriya \\ Program studi pascasarjana Ilmu Lingkungan Universitas Andalas \\ Email: nofriya_firdaus@yahoo.com
}

\begin{abstract}
ABSTRAK
Persediaan Bahan Bakar Minyak (BBM) semakin menipis dan suatu saat dapat habis sama sekali. Pemakaian energi dari BBM juga menghasilkan polusi dan berakibat pada pemanasan global. Diperlukan upaya pengadaan energi alternatif untuk mengurangi ketergantungan terhadap bahan bakar yang bersumber dari fosil, sehingga perlu dikembangkan pemanfaatan energi baru dan terbarukan seperti biofuel. Akan tetapi, proses budidaya beberapa tanaman sebagai sumber biofuel memerlukan lahan cukup luas dan lahan yang tersedia lebih diprioritaskan terhadap lahan budidaya tanaman pangan. Perairan Indonesia sebagai wilayah tropika memiliki sumberdaya plasma nutfah rumput laut sebesar $6,42 \%$ dari total biodiversitas rumput laut dunia. Luas wilayah yang menjadi habitat rumput laut di Indonesia sekitar 1,2 juta hektar sehingga rumput laut memiliki potensi yang sangat besar untuk dimanfaatkan sebagai sumber bietanol tanpa harus menggunakan lahan yang dapat digunakan untuk kebutuhan pangan. Teknik yang dilakukan adalah dengan proses hidrolisa, fermentasi, kemudian dilakukan pemurnian dengan distilasi.
\end{abstract}

\section{Kata kunci: energi alternatif, biofuel, rumput laut}

\section{ABSTRACT}

Stock of fuel oil is dwindling and somotime could run out. Energy consumption of fuel also produce pollution and cause global warming. Alternative energy procurement efforts are needed to reduce dependence on fossil fuels, so it is necessary to develop the use of new and renewable energy such as biofuels. However, the process of cultivating some plants as a source of biofuel requires wide land and the available land is prioritized to the cultivation of food. Indonesian's sea as tropical areas have seaweed germplasm resources of $6.42 \%$ of the total world seaweed biodiversity. The total area as a habitat of seaweed in Indonesia about 1.2 million hectares, so that seaweed has a huge potential to be used as a source of bietanol without having to use the land that can be used for food. Technique is done by hidrolysis, fermentation, then purified by distillation.

Keywords: alternative energy, bioethanol, seaweed 


\section{PENDAHULUAN}

Semakin lama kebutuhan terhadap energi setiap hari semakin meningkat. Akan tetapi persediaan energi terutama dari Bahan Bakar Minyak (BBM) makin menipis dan suatu saat dapat habis sama sekali. Pemakaian energi dari BBM seperti premium, solar dan minyak tanah juga menghasilkan polusi dan berakibat pada pemanasan global. Salah satu dampak pemanasan global adalah terjadinya kenaikan temperatur yang menyebabkan kenaikan permukaan air laut sekitar 10-25 $\mathrm{cm}$, dan diprediksi pada tahun 2100 temperatur akan meningkat $6^{\circ} \mathrm{C}$. Jika tidak dilakukan pengendalian akan mengakibatkan penurunan kualitas umat manusia. Oleh sebab itu diperlukan upaya pengadaan energi alternatif untuk mengurangi ketergantungan terhadap bahan bakar minyak yang bersumber dari fosil (Dyah, 2014).

Berkurangnya persediaan sumber daya alam untuk BBM tersebut adalah tantangan bagi semua pihak. Seperti yang tertera pada UU no 30 Tahun 2007 tentang Energi menyebutkan bahwa pemerintah wajib menyediakan energi terbaru dan terbarukan sebagai bagian dari diversifikasi energi dan juga tanggungjawab semua pihak. Dalam upaya mengatasi krisis ini perlu dilakukan pengembangan pemanfaatan energi nonminyak bumi. Hal ini perlu dikembangkan pemanfaatan energi baru dan terbarukan seperti biofuel (biodiesel dan bioetanol), panas bumi, Coal Bed Methane (CBM), biogas, energi air, energi matahari, energi angin, energi nuklir (Hasjim dan Toha, 2013).

Pemerintah juga telah meluncurkan berbagai program untuk mengatasi masalah berkurangnya persediaan BBM, salah satunya adalah pemanfaatan minyak jarak, minyak sawit, ubi kayu dan berbagai bijibijian digunakan sebagai bahan baku BBN (Bahan Bakar Nabati) terbarukan. Akan tetapi, proses budidaya beberapa tanaman ini memerlukan lahan cukup luas. Hal ini merupakan salah satu kendala di lapangan karena lahan yang tersedia lebih diprioritaskan terhadap lahan budidaya tanaman pangan (Dyah, 2014).
Dua per tiga kawasan Indonesia merupakan wilayah perairan. Pada tahun 1982 United Nation Convention on the Law of the Sea (UNCLOS) melaporkan bahwa luas perairan Indonesia adalah 5,8 juta $\mathrm{km}^{2}$ dan di dalamnya terdapat $27,2 \%$ dari seluruh spesies flora dan fauna di dunia (Pangestuti dan Leemantara, 2007). Salah satu potensi terbesar yang dapat digunakan sebagai BBN yang berada dalam perairan Indonesia adalah rumput laut.

Rumput laut atau lebih dikenal dengan sebutan seaweed merupakan salah satu sumber daya hayati yang sangat melimpah di perairan Indonesia yaitu sekitar 8,6\% dari total biota di laut (Dahuri, 1998). Luas wilayah yang menjadi habitat rumput laut di Indonesia sekitar 1,2 juta hektar dan merupakan habitat rumput laut terbesar di dunia (Wawa, 2005). Di Indonesia terdapat kurang lebih 555 jenis dari 8642 spesies rumput laut yang terdapat di dunia. Dengan kata lain perairan Indonesia sebagai wilayah tropika memiliki sumberdaya plasma nutfah rumput laut sebesar $6,42 \%$ dari total biodiversitas rumput laut dunia (Pangestuti dan Leemantara, 2007).

Proses pembudidayaan rumput laut tidak akan mengurangi lahan pertanian pangan dikarenakan luas lautan di wilayah Indonesia sekitar 2/3. Hal ini dapat menjadi pertimbangan utama untuk mengatasi masalah kelangkaan bahan bakar di masa depan. Indonesia merupakan negara kepulauan yang memiliki panjang pantai sekitar $81.000 \mathrm{~km}$ memilki potensi bahan baku rumput laut untuk energi alternatif yang dapat dimanfaatkan sebagai bietanol. Rumput laut memiliki potensi sebagai penghasil bioenergi. Bioenergi berasal dari makhluk hidup yang dibudidayakan oleh manusia dan selanjutnya dipanen dan diolah menjadi bahan bakar secara berkesinambungan (Prihandana dkk, 2007).

Rumput laut yang melimpah di perairan Indonesia adalah bahan tumbuhan prospektif bagi kemandirian energi alternatif dari tumbuh-tumbuhan. Pemanfaatan rumput laut di Indonesia sampai saat ini terbatas sebagai bahan makanan bagi penduduk yang tinggal di daerah pesisir dan belum dimanfaatkan lebih lanjut, apalagi untuk mengatasi 
masalah energi (Dyah, 2014). Oleh karena itu, pemanfaatan rumput laut menjadi sumber bahan bakar dimasa depan merupakan potensi yang besar untuk mengurangi ketergantungan terhadap BBM.

\section{BAHASAN UTAMA}

\section{Rumput Laut}

Rumput laut atau seaweed adalah salah satu tumbuhan laut yang termasuk dalam golongan makroalga benthik yang umumnya hidup melekat di dasar perairan. Rumput laut merupakan ganggang yang hidup di laut dan tergolong dalam divisi thallophyta. Berdasarkan kandungan pigmennya, klasifikasi rumput laut terbagi ke dalam 4 kelas, yaitu rumput laut hijau (Chlorophyta), rumput laut merah (Rhodophyta), rumput laut coklat (Phaeophyta) dan rumput laut pirang (Chrysophyta).

Seluruh bagian tumbuhan rumput laut disebut thallus, sehingga rumput laut tergolong tumbuhan tingkat rendah. Bentuk thallus rumput laut bermacam-macam, ada yang bulat seperti tabung, pipih, gepeng, bulat seperti kantong, rambut, dan lain sebagainya. Thallus dapat tersusun hanya oleh satu sel (uniseluler) atau banyak sel (multiseluler). Percabangan thallus ada yang thallus dichotomus (dua-dua terus menerus), pinate (dua-dua berlawanan sepanjang thallus utama), pectinate (berderet searah pada satu sisi thallus utama) dan ada juga yang sederhana tidak bercabang. Sifat substansi thallus juga beraneka ragam ada yang lunak seperti gelatin (gelatinous), keras diliputi atau mengandung zat kapur (calcareous), lunak bagaikan tulang rawan (cartilagenous), berserabut (spongeous) dan sebagainya dengan berbagai keanekaragaman warna (Soegiarto dkk, 1978).

Van Bosse melalui ekspedisi Laut Siboga pada tahun 1899-1900 melaporkan bahwa Indonesia memiliki sekitar 555 jenis dari 8.642 spesies rumput laut yang terdapat di dunia. Dengan kata lain, perairan Indonesia sebagai wilayah tropis memiliki sumberdaya plasma nutfah rumput laut sebesar $6,42 \%$ dari total biodiversitas rumput laut dunia (Santosa, 2003). Rumput laut dari kelas alga merah (Rhodophyceae) menempati urutan terbanyak dari jumlah jenis yang tumbuh di perairan laut Indonesia yaitu sekitar 452 jenis, setelah itu alga hijau (Chlorophyceae) sekitar 196 jenis dan alga coklat (Phaeophyceae) sekitar 134 (Winarno, 1996). Dibalik peran ekologis dan biologisnya dalam menjaga kestabilan ekosistem laut serta sebagai tempat hidup sekaligus perlindungan bagi biota lain, golongan makroalga ini memiliki potensi ekonomis yaitu sebagai bahan baku dalam industri dan kesehatan.

Adapun faktor-faktor yang sangat mempengaruhi pertumbuhan rumput laut dapat dijabarkan sebagai berikut (Eidman, 1991).

\section{Suhu}

Wilayah pantai dipengaruhi oleh suhu udara selama periode yang berbedabeda dan suhu ini mempunyai kisaran yang luas baik secara harian maupun secara musiman. Perubahan suhu ini terjadi saat terjadinya pasang atau surut maksimal. Suhu juga mempunyai pengaruh tidak langsung terhadap organisme laut. Organisme laut dapat mati kehabisan air, meningkatnya suhu dapat mempercepat kehabisan air. Suhu air di permukaan nusantara berkisar antara $28-31^{\circ} \mathrm{C}$.

Suhu di dekat pantai biasanya sedikit lebih tinggi dari pada di lepas pantai. Suhu perairan sangat mempengaruhi laju fotosintesis, nilai suhu perairan yang optimal untuk laju fotosintesis berbeda pada setiap jenis rumput laut. Secara prinsip suhu yang tinggi dapat menyebabkan protein mengalami denaturasi, serta dapat merusak enzim dan membran sel yang bersifat labil terhadap suhu yang tinggi. Pada suhu yang rendah, protein dan lemak membran dapat mengalami kerusakan sebagai akibat terbentuknya kristal di dalam sel. Terkait dengan itu, maka suhu sangat mempengaruhi beberapa hal yang terkait dengan kehidupan rumput laut, seperti kehilangan hidup, pertumbuhan dan perkembangan, reproduksi, fotosintesis dan respirasi. Selanjutnya menurut Sulistijo (1994) menyatakan kisaran suhu perairan laut 
yang baik untuk rumput laut jenis Eucheuma adalah berkisar antara 27 $30^{\circ} \mathrm{C}$.

2. Arus

Arus merupakan gerakan mengalir suatu masa air yang dapat disebabkan oleh tiupan angin, perbedaan densitas air laut dan pasang surut yang bergelombang panjang dari laut terbuka. Arus mempunyai peranan penting dalam penyebaran unsur hara di laut. Arus ini sangat berperan dalam perolehan makanan bagi alga laut karena arus dapat membawa nutrien yang dibutuhkan dalam perkembangan rumput laut.

Aslan (1991) menyatakan bahwa dalam budidaya rumput laut, kerugian yang ditimbulkan bila ombak atau gelombang cukup kuat adalah rumput laut kesulitan menyerap nutrisi yang berguna bagi pertumbuhan, perairan menjadi keruh sehingga menghalangi proses fotosintesis, dan menurut Sulistijo (1994), salah satu syarat untuk menentukan lokasi rumput laut adalah adanya arus dengan kecepatan 0,33 $0,66 \mathrm{~m} /$ detik.

3. Salinitas

Salinitas merupakan kadar garam yang terkandung dalam air laut. Perubahan salinitas dapat mempengaruhi organiseorganisme yang hidup di laut dan zona intertidal (Nybakken, 1992). Pada keadaan tertentu penurunan salinitas yang melewati batas toleransi akan mengakibatkan matinya organisme tertentu. Salinitas akan mengalami penurunan saat hujan dan mengalami kenaikan saat siang hari yaitu saat terjadi penguapan.

Kenaikan salinitas akan menurunkan potensi air yang menyebabkan percepatan plasmolisis sel dan stress pada rumput laut. Rumput laut di daerah intertidal dapat mentoleransi perubahan salinitas lebih baik dibandingkan rumput laut di daerah subtidal.

4. $\mathrm{pH}$

Keasaman atau derajat $\mathrm{pH}$ merupakan salah satu faktor penting dalam kehidupan alga laut, sama halnya dengan faktor-faktor lainnya. Aslan (2005) menyatakan bahwa kisaran $\mathrm{pH}$ maksimum untuk kehidupan organisme laut adalah 6,5 - 8,5.

5. Pasang Surut

Pasang-surut terjadi karena interaksi antara gaya gravitasi matahari dan bulan terhadap bumi serta gaya sentrifugal yang ditimbulkan oleh rotasi bumi dan sistem rotasi bulan. Pasangsurut berpengaruh terhadap kehidupan rumput laut. Pola pasang surut mempengaruhi struktur komunitas rumput laut. Perbedaan pasang surut yang terlalu tinggi dapat menghambat budidaya rumput laut. Perbedaan pasang surut yang terlalu tinggi menyebabkan spine (ujung tanaman) menjadi kering dan rusak.

6. Substrat dan Nutrien

Tipe dan sifat substratum dan dasar perairan merupakan faktor penting dalam pemilihan lokasi. Keadaan substratum ini merupakan refleksi dari keadaan oseanografi perairan karang dan dapat pula digunakan untuk menentukan derajat kemudahan dalam pembangunan konstruksi budidaya rumput laut.

\section{Sumber Energi}

Terdapat banyak sumber-sumber energi utama dan digolongkan menjadi dua yaitu (Vries dkk, 2010).

1. Energi Konvensional.

Energi konvensional adalah energi yang diambil dari sumber yang hanya tersedia dalam jumlah terbatas di bumi dan tidak dapat diregenerasi. Sumber-sumber energi ini akan berakhir cepat atau lambat dan relatif berbahaya bagi lingkungan. Sumber-sumber energi konvensional pada umumnya tidak ramah lingkungan karena dapat menimbulkan polusi udara, air, dan tanah yang berdampak kepada penurunan tingkat kesehatan dan standar hidup.

Sumber-sumber energi konvensional primer diambil dari tanah dalam bentuk cair (minyak dan petroleum), gas (gas alam) dan padat (batubara \& uranium). Campuran udara dan bahan bakar fosil dibakar di dalam mesin dan energi panas 
yang dihasilkan dikonversi menjadi energi mekanik yang menggerakkan sepeda motor, mobil atau kapal.

Minyak pada umumnya dibakar pada generator mesin diesel, yang membangkitkan listrik atau digunakan sebagai pasokan listrik cadangan. Generator mesin diesel bekerja dengan cara yang sama dengan mesin mobil. Namun, energi mekanik yang digunakan untuk menggerakkan poros genset digunakan untuk menghasilkan energi listrik. Batubara dan gas alam dibakar di pembangkit listrik thermal untuk menghasilkan listrik dengan skala besar. Pembangkit listrik tenaga batubara adalah pembangkit listrik thermal paling awal dibangun yang menggunakan bahan bakar fosil. Pembangkit listrik tenaga batu bara membakar batubara untuk memanaskan air yang digunakan untuk menggerakkan turbin uap, terutama baling-baling besar dengan bilah-bilah logam yang dikemas rapat untuk membangkitkan tenaga.

\section{Energi Terbarukan}

Energi terbarukan adalah energi yang dihasilkan dari sumber alami seperti matahari, angin, dan air serta dapat dihasilkan terus menerus. Sumber alami akan selalu tersedia dan tidak merugikan lingkungan. Terdapat beragam jenis energi terbarukan seperti tenaga surya, tenaga angin, biomassa dan tenaga air, panas bumi dan energi pasang surut.

Indonesia memiliki sumber panas bumi yang melimpah yakni sekitar $40 \%$ dari sumber total dunia. Akan tetapi sumbersumber ini berada di tempat-tempat yang spesifik dan tidak tersebar luas. Teknologi energi terbarukan lainnya adalah tenaga ombak, yang masih dalam tahap pengembangan. Adapun contoh energi terbarukan adalah sebagai berikut.

a. Matahari

Matahari terletak 149 juta kilometer dari Bumi dan menghasilkan jumlah energi yang luar biasa banyaknya. Energi yang dipancarkan oleh matahari yang mencapai Bumi setiap menit akan cukup untuk memenuhi kebutuhan energi seluruh penduduk manusia di planet bumi selama satu tahun, jika bisa ditangkap dengan benar.

b. Angin

Pada saat angin bertiup, angin disertai dengan energi kinetik (gerakan) yang bisa melakukan suatu pekerjaan. Contoh, perahu layar memanfaatkan tenaga angin untuk mendorongnya bergerak di air.

c. Biomassa

Merupakan salah satu sumber energi yang telah digunakan manusia sejak dari jaman dahulu kala. Manusia menggunakan kayu bakar untuk memasak makanan selama ribuan tahun. Biomassa adalah semua benda organik (misal: kayu, tanaman pangan, limbah hewan dan manusia) dan bisa digunakan sebagai sumber energi untuk memasak, memanaskan dan pembangkit listrik. Sumber energi ini bersifat terbarukan karena pohon dan tanaman pangan akan selalu tumbuh dan akan selalu ada limbah tanaman. Ada empat jenis biomassa:

1) Terurai di alam. Kayu serta limbah pertanian bisa dibakar dan digunakan untuk menghasilkan uap dan listrik. Banyak listrik yang digunakan oleh industri menghasilkan limbah yang bisa dipakai untuk menggerakkan mesin mereka sendiri (contoh: produsen furnitur).

2) Bahan bakar padat limbah anorganik. Pembangkit listrik yang memanfaatkan sampah untuk menghasilkan energi disebut pembangkit listrik tenaga sampah.

3) Bahan bakar gas. Sampah yang ada di tempat pembuangan sampah akan membusuk dan menghasilkan gas metan. Jika gas metan tersebut ditampung, maka bisa langsung dimanfaatkan untuk dibakar yang menghasilkan panas untuk penggunaan praktis atau digunakan pada pembangkit listrik untuk menghasilkan listrik. Metan bisa juga dihasilkan 
dengan menggunakan kotoran hewan dan manusia dalam metode yang terkendali.

4) Bahan bakar hayati berbentuk cair. Bahan bakar hayati adalah bahan bakar untuk kendaraan bermotor atau mesin. Bahan bakar ini bisa digunakan sebagai tambahan atau menggantikan bahan bakar konvensional untuk mesin. Bioetanol adalah alkohol yang dibuat melalui proses fermentasi gula yang terkandung pada tanaman pangan (contoh: tebu, ubi kayu atau jagung), dan digunakan sebagai tambahan untuk bensin. Biodiesel dibuat dari minyak sayur (misal: Minyak Sawit, Jatropha Curcas, Minyak Kelapa, atau Minyak Kedelai, atau Limbah Minyak Sayur/WVO. Biodiesel bisa digunakan sendiri atau sebagai tambahan pada mesin diesel tanpa memodifikasi mesin.

d. Tenaga air, adalah energi yang diperoleh dari air yang mengalir atau air terjun. Air yang mengalir ke puncak baling-baling atau balingbaling yang ditempatkan di sungai, akan menyebabkan baling-baling bergerak dan menghasilkan tenaga mekanis atau listrik. Tenaga air sudah cukup dikembangkan dan terdapat banyak pembangkit listrik tenaga air (PLTA) yang menghasilkan listrik.

e. Energi panas bumi, adalah energi panas yang berasal dari dalam Bumi. Pusat Bumi cukup panas untuk melelehkan bebatuan. Tergantung pada lokasinya, maka suhu Bumi meningkat satu derajat celsius setiap penurunan 30 hingga $50 \mathrm{~m}$ di bawah permukaan tanah. Suhu Bumi 3000 meter di bawah permukaan cukup panas untuk merebus air. Kadangkadang, air bawah tanah merayap mendekati bebatuan panas dan menjadi sangat panas atau berubah menjadi uap. Pembangkit Listrik Tenaga Panas Bumi (PLTPB) adalah seperti pembangkit listrik tenaga batu bara biasa, hanya tidak memerlukan bahan bakar. Uap atau air panas langsung berasal dari bawah tanah dan menggerakkan turbin yang dihubungkan dengan generator yang menghasilkan listrik.

f. Air pasang naik dan turun, dapat menggerakkan volume air yang sangat banyak saat tingkat air laut naik dan turun di sepanjang garis pantai. Energi air pasang bisa dimanfaatkan untuk menghasilkan listrik seperti halnya listrik tenaga air.

Adapun manfaat dari energi terbarukan adalah:

a. Tersedia secara melimpah.

b. Lestari tidak akan habis.

c. Ramah lingkungan (rendah atau tidak ada limbah dan polusi).

d. Sumber energi bisa dimanfaatkan secara cuma-cuma dengan investasi teknologi yang sesuai.

e. Tidak memerlukan perawatan yang banyak dibandingkan dengan sumbersumber energi konvensional dan mengurangi biaya operasi.

f. Membantu mendorong perekonomian dan menciptakan peluang kerja.

g. Tidak perlu mengimpor bahan bakar fosil dari negara ketiga.

h. Lebih murah dibandingkan energi konvensional dalam jangka panjang.

i. Bebas dari fluktuasi harga pasar terbuka bahan bakar fosil.

j. Beberapa teknologi mudah digunakan di tempat-tempat terpencil.

k. Distribusi energi bisa diproduksi di berbagai tempat, tidak tersentralisir.

\section{Bioetanol}

Bioetanol merupakan bahan bakar yang dibuat dari fermentasi tanaman yang mengandung jumlah kandungan gula, pati atau selulosa yang tinggi sehingga dapat diperoleh etanol murni untuk digunakan sebagai bahan bakar. Di Indonesia bioetanol umumnya dibuat dari tanaman seperti singkong (umbi), ubi (umbi), tebu (tangkai dan molase), jagung (gandum), sorgum (gandum), sorgum manis (tangkai), sagu (tangkai), padi (tangkai) dan nira dari Aren, Niphar, Lontar, dan Kelapa.

Metode produksi yang digunakan adalah pencernaan dengan bantuan enzim untuk 
melepaskan gula dari pati tanaman, fermentasi gula, penyulingan dan pengeringan. Proses penyulingan memerlukan asupan energi dalam bentuk panas. Salah satu ketakutan utama menggunakan biofuel adalah terjadinya persaingan dengan produksi pangan (ini akan berkurang dengan produksi etanol berbasis selulosa). Pembukaan lahan baru untuk pertanian tanaman energi sering dilakukan dengan cara dibakar. Hal ini menyebabkan kerusakan lingkungan seperti penggundulan hutan dan penurunan kesuburan tanah karena pengurangan bahan organik. Pembakaran juga menghasilkan emisi karbon dioksida yang sangat besar. Kelemahan etanol lainnya adalah biaya produksi dan fakta bahwa etanol membutuhkan air yang sangat besar (Vries dkk, 2010). Oleh karena itu diperlukan alternatif lain dalam menghasilkan biotanol yaitu berasal dari rumput laut.

\section{Permasalahan Energi yang Dihadapi Saat Ini}

Permasalahan sektor energi timbul karena adanya laju pertumbuhan peningkatan permintaan energi akibat kegiatan ekonomi dan bertambahnya jumlah penduduk, yang melebihi laju pertumbuhan pasokan energi. Selain itu kondisi geografis negara kepulauan, yang terdiri atas belasan ribu pulau besar dan kecil, serta luasnya wilayah nusantara, mempengaruhi tingkat pelayanan, efisiensi dan keandalan sistem penyediaan dan penyaluran energi di seluruh Indonesia (Munawar, 2014).

Dalam beberapa waktu terakhir, volume pemakaian bahan bakar fosil masih bertambah dari tahun ke tahun. Kesenjangan antara konsumsi BBM dengan kemampuan memproduksi minyak mentah dan BBM di dalam negeri telah menyebabkan ketergantungan yang besar terhadap impor, baik impor minyak mentah maupun BBM. Ketergantungan terhadap impor ini menyebabkan ketahanan energi nasional menjadi rentan terhadap fluktuasi harga serta pasokan/permintaan minyak mentah dunia. Kesenjangan antara pasokan dan permintaan BBM dalam negeri juga disebabkan oleh menurunnya produksi minyak mentah dalam beberapa tahun terakhir. Hal ini terjadi karena sebagian besar (lebih dari 90\%) lapangan minyak yang saat ini beroperasi merupakan lapangan minyak tua (mature), sedangkan penambahan lapangan minyak baru tidak dapat mengimbangi laju kebutuhan minyak mentah dalam negeri. Salah satu kendala utama pembukaan lapangan minyak baru adalah adanya konflik atau ketidakselarasan fungsi lahan, terutama dengan fungsi kawasan hutan konservasi dan lindung. Selain itu kendala lain adalah keterbatasan permodalan nasional, sehingga ketergantungan terhadap investor asing masih cukup tinggi (Vries dkk, 2010).

Ketergantungan terhadap impor BBM juga disebabkan oleh karena infrastrukur kilang minyak masih sangat terbatas kapasitasnya. Saat ini, terdapat 10 (sepuluh) kilang minyak yang beroperasi, baik yang dimiliki oleh PT Pertamina (Persero) maupun oleh badan usaha swasta, dengan total kapasitas pengolahan sebesar 1,156 juta barel per hari. Karena konfigurasinya, tidak semua kilang yang ada dapat memproses minyak mentah dari dalam negeri dan hanya dapat memproses minyak mentah impor.

Pada tahun 2008, sebanyak $60 \%$ dari total produksi minyak mentah dimanfaatkan untuk keperluan Bahan Bakar Minyak (BBM) dalam negeri, dan sisanya diekspor. Namun pasokan minyak mentah ini masih belum cukup untuk memenuhi permintaan BBM nasional, yakni sebesar 1.038 barel per hari. Sehingga masih diperlukan impor minyak mentah dan BBM. Pada tahun 2008, untuk memenuhi kebutuhan BBM dalam negeri, sebanyak 247 barel per hari minyak mentah dan sebanyak 423 barel per hari BBM dipasok dari pasar internasional.

Oleh karena ada kekuatiran mengenai keamanan energi dan perubahan iklim, maka Indonesia berencana untuk meningkatkan porsi pemanfaatan energi terbarukan, yang sangat sesuai untuk dikembangkan di daerah-daerah perdesaan dan daerah terpencil. Kebijakan Energi Nasional saat ini telah menetapkan target pembangunan energi jangka-panjang, meningkatkan peran energi yang baru dan terbarukan hingga $25 \%$ dari konsumsi energi primer pada tahun 2025. 
Dukungan yang lebih besar dari para pemangku kepentingan dan pelaksanaan teknologi yang telah disempurnakan bisa melampaui sasaran tersebut, di mana 25\% sumber-sumber energi berasal dari sumber energi baru dan terbarukan pada tahun 2025 (Dyah, 2014).

\section{Gambaran Umum Teknik Penggunaan Rumput Laut Menjadi Sumber Energi Alternatif}

Menurut Harvey (2009), secara kimia rumput laut terdiri dari air $(27,8 \%)$, protein $(5,4 \%)$, karbohidrat $(33,3 \%)$, lemak $(8,60 \%)$, serta serat kasar $(3,0 \%)$, dan abu $(22,25 \%)$ dan menurut Suriawiria (2003), uji proksimat yang dilakukan pada limbah rumput laut kering didapatkan presentase masing-masing komponen kadar air adalah $11.28 \%$, kadar abu 36,05\%, kadar lemak $0,42 \%$, kadar protein $1.86 \%$, kadar serat kasar $8,96 \%$ dan karbohidrat $41,43 \%$. Hal ini membuktikan bahwa rumput laut memiliki kandungan selulosa yang tinggi.

Adapun proses pembuatan bioetanol dari rumput laut adalah sebagai berikut (Dyah, 2014).

1. Persiapan bahan baku, yang berupa proses hidrolisa pati menjadi glukosa. Hidrolisis selulosa menjadi gula-gula sederhana dapat dilakukan menggunakan enzim-enzim kelompok hidrolase (Duff and Murray, 1996). Hidrolisis selulosa secara enzimatis menghasilkan gula pereduksi (glukosa). Enzim selulase menghidrolisis selulosa menjadi glukosa. Tiga enzim utama yang terdapat dalam selulase kompleks yaitu endoglukanase, eksoglukanase, dan selobiase ( $\beta$-glukosidase) (Syamsudin et.al 2008).

2. Proses fermentasi, merubah glukosa menjadi etanol dan $\mathrm{CO}_{2}$. Secara garis besar, fermentasi karbohidrat terdiri dari:

a. Pemecahan karbohidrat (pati) menjadi gula pereduksi. Pemecahan karbohidrat menjadi gula pereduksi karena difermentasi oleh enzim diastase dan zymase yang terkandung dalam ragi.

b. Perubahan gula pereduksi menjadi etanol. Perubahan gula pereduksi menjadi etanol dilakukan oleh enzyme invertrase, yaitu enzim kompleks yang terkandung dalam ragi.

c. Fermentasi Asam Asetat. Merupakan kelanjutan dari proses fermentasi alkohol. Proses dimulai dari proses pemecahan gula menjadi alkohol, selanjutnya alkohol menjadi asam asetat.

3. Pemurnian hasil dengan cara distilasi.

Hal-hal yang perlu diperhatikan dalam pemilihan lokasi budidaya rumput laut adalah sebagai berikut (Yunizal dkk, 1999).

1. Keterlindungan lokasi, dimana lokasi harus terlindung untuk menghindari kerusakan fisik rumput laut dari terpaan angin dan gelombang yang besar.

2. Dasar perairan yang paling baik bagi pertumbuhan rumput laut adalah dasar perairan yang stabil yang terdiri dari potongan karang mati bercampur dengan pasir karang, dan adanya seagrass. Hal ini menunjukkan adanya gerakan air yang baik.

3. Kedalaman air berkisar antara $30-50$ $\mathrm{cm}$ pada surut terendah, supaya rumput laut tidak mengalami kekeringan karena terkena sinar matahari secara langsung dan masih memperoleh penetrasi sinar matahari pada waktu pasang. Kedalaman maksimal adalah setinggi orang berdiri dengan mengangkat tangannya.

\section{Manfaat Rumput Laut sebagai Sumber Energi Alternatif}

Keberadaan rumput laut sebagai sumber energi alternatif tidak akan mengganggu pemanfaatan lahan daratan. Kegunaan rumput laut sangat luas, dan dekat sekali dengan kehidupan manusia. Saat ini sumber energi dunia masih didominasi oleh sumber yang tidak terbarukan (minyak, batubara, dan gas), yakni sekitar $80,1 \%$, dimana masing-masing adalah minyak sebesar $35,03 \%$, batubara sebanyak $24,59 \%$ dan gas $20,44 \%$. Sumber energi terbarukan, tapi mengandung risiko tinggi adalah energi nuklir sekitar 6,3\%. Sumber energi yang terbarukan baru sekitar 13,6\%, terutama 
biomassa tradisional sekitar 8,5\% (Maulana dan Wibowo, 2011).

Etanol adalah bahan bakar ramah lingkungan. Menggunakan etanol (dibanding bensin) mengurangi emisi karbon monoksida, partikel, oksida nitrogen, dan polutan ozon lainnya. Campuran bahan bakar etanol dapat mengurangi emisi karbon monoksida sampai dengan $25 \%$ dan emisi gas rumah kaca sampai dengan $35-45 \%$.

Menurut Berglihn dkk (2012), beberapa keuntungan rumput laut untuk dijadikan bahan baku bioetanol adalah memiliki kandungan selulosa yang tinggi, tidak mengandung lignin, tidak membutuhkan air bersih, dan tidak membutuhkan tanah untuk berkembang. Selain itu, rumput laut tahan terhadap panas dan tidak mudah terbiodegradasi (Hughes dkk, 2013)

Beberapa penelitian sebelumnya telah membahas tentang pemanfaatan makroalga sebagai bahan bakar alternatif, salah satunya adalah penelitian dari Jorge Alberto Vieira Costa dan Michele Greque de Morais dari Laboratory of Biochemical Engineering, College of Chemistry and Food Engineering, Federal University of Rio Grande, Brazil yang melaporkan bahwa alga ternyata dapat dijadikan sebagai sumber bahan baku utama dalam pembuatan biofuel pengganti energi fosil karena ramah lingkungan, dan mampu mengurangi emisi gas karbondioksida yang berdampak pada efek rumah kaca dan pemanasan global. Seiring dengan itu, penelitian yang dilakukan oleh Murphy dkk (2013) menyebutkan bahwa penggunaan rumput laut sebagai bahan bakar diperkirakan dapat menurunkan emisi gas rumah kaca $35 \%$ hingga $60 \%$.

Rumput laut dapat menghasilkan 200 liter bioetanol, berarti dari setiap hektar diperoleh 7.200 - 9.600 liter per tahun (Utama, 2009). Hal ini lebih besar dibandingkan dengan bioetanol yang dihasilkan dari sorgum manis (2500-7000 liter/ha) dan jagung (3100-4000 liter/ha) (Bourne dan Clark, 2007). Menurut Departement of Energy Amerika Serikat, rumput laut mempunyai potensi 100 kali lebih banyak menghasilkan bioetanol dibandingkan dengan kedelai.
Potensi pengembangan bioetanol rumput laut juga lebih besar dibandingkan dengan pengembangan bioetanol berbahan baku tebu. Data survey menunjukkan ketersediaan lahan di luar Jawa yang sesuai untuk tebu terdapat sekitar 750 ribu ha, disamping potensi arael existing industri seluas 420 ribu ha. Luas ini lebih kecil dibandingkan potensi lahan budidaya rumput laut yang mencapai 2,1 juta ha. Selain itu 80 liter bioetanol dapat dihasilkan dari 1 ton tebu (data teknis di Brazil) dan produktivitas tebu rata-rata 80 ton per ha, maka dari setiap ha lahan tebu dapat dihasilkan 6.400 liter etanol. Apabila etanol dari tebu dapat mensubstitusi $10 \%$ dari kebutuhan gasoline (33,4 milyar liter), maka target tersebut bisa dicapai dengan pengembangan areal tebu seluas 522 ribu ha. Dengan target subsitusi tersebut, jumlah bioetanol yang dapat disubstitusi sebesar 3,34 milyar liter atau lebih dari $\mathrm{Rp} 15$ triliun. Sedangkan produktivitas rumput laut rata-rata 25 ton per ha per panen (umur panen 2 bulan), maka akan dihasilkan rumput laut 100-125 ton per ha per tahun. Tentunya akan menghasilkan bioetanol yang lebih besar lagi (Dyah, 2014).

\section{SIMPULAN}

Pemanfaatan rumput laut sebagai energi alternatif merupakan potensi yang sangat besar, dikarenakan luas lautan yang terdiri dari dua per tiga wilayah bumi sehingga tidak akan mengurangi pemanfaatan lahan untuk kebutuhan penyediaan bahan pangan pokok. Rumput laut juga dapat menghasilkan etanol yang lebih banyak daripada tumbuhan lain. Teknologi yang dilakukan cukup sederhana yaitu hidrolisa pati menjadi glukosa, fermentasi dan proses distilasi. Hal ini cukup mudah dan memungkinkan dilakukan dalam skala besar, sehingga dapat mengurangi pemakaian BBM yang ketersediaannya semakin menipis. 


\section{DAFTAR PUSTAKA}

Aslan, L.M. 1998. Budidaya Rumput Laut. Kanisius. Yogyakarta.

Bourne, J.K dan Clark, R. 2007. Green Dreams. National Geographic Magazine October 2007.

Dahuri, Rokhmin. 1998. Coastal Zone Management in Indonesia: Issues and Approaches. Journal of Coastal Development 1, No. 2.

Dyah B. Rumput Laut: Sumber Energi Alternatif. www.esdm.go.id.

Eidman, M. 1991. Studi Efektivitas Bibit Algae Laut (Rumput Laut) Salah Satu Upaya Peningkatan Produksi Budidaya Algae Laut (Eucheuma sp.). Laporan Penelitian. Fakultas Perikanan. Institut Pertanian Bogor.

Harvey F. 2009. Produksi Etanol dari Limbah Karaginan. Skripsi. Departemen Teknologi Hasil Perairan. Fakultas Perikanan dan llmu Kelautan. Insitut Pertanian Bogor.

Hasjim, M dan Toha, T. 2013. Pengembangan Energi Non-Minyak Bumi Yang Ramah Lingkungan. Laporan Penelitian. Universitas Sriwijaya.

Hughes, A.D., Kenny D. B., Iona., Keith D., Maeve., Michael S.S. 2013. Does seaweed offer a solution for bioenergy with biological carbon capture and storage? Greenhouse Gas Sci Technol. No. 2. Scottish Association for Marine Science, Argyll, Scotland.

Maulana., P dan Wibowo., A.S. 2011. Mengganti Bensin dengan Rumput Laut. Yayasan Rumput Laut Indonesia. Semarang.

Munawar. 2014. Memahami Pengertian dan Kebijakan Subsidi dalam APBN. www.bppk.kemenkeu.go.id.

Murphy, F., Ger D., Rory D., Kevin M. 2013. Biofuel Production in IrelandAn Approach to 2020 Targets with a Focus on Algal Biomass. Energies Vol I.
Nybakken, J.W. 1992. Biologi Laut, Suatu Pendekatan Ekologi. PT.Gramedia. Jakarta.

Olaf T. Berglihn, Inga M. Aasen, Bernd Wittgens. 2012. Conversion of Seaweed to Biofuels: Potential and Challenges Workshop- Seaweed for Biofuel Trondheim 25. September 2012.

Pangestuti, R dan Leemantara, K. 2007. Sejuta Manfaat Warna yang Tak Tergali Dari Rumput Laut. Makalah disampaikan dalam Seminar Pigmen Rumput Laut di Jurusan Ilmu Kelautan FPIK Universitas Diponegoro, Semarang (4 Agustus 2007).

Prihandana, R., E. Hambali, S. Mujdalifah dan R. Hendroko. 2007. Meraup Untung dari Jarak Pagar. Agromedia Pustaka Utama. Jakarta.

Santosa, G.W. 2003. Budidaya Rumput Laut. Program Community CollegeIndustri Kelautan dan Perikanan. Universitas Diponegoro. Semarang.

Soegiarto, A. Sulistijo. W, S, Atmaja dan H, Mubarak. 1978. Rumput Laut, Manfaat, Potensi, dan Usaha Budidayanya. LONLIPI. Jakarta.

Sulistijo.1996. Perkembangan Budidaya Rumput Laut Di Indonesia. Puslitbang Oseanologi. LIPI. Jakarta.

U.S Departement Of Energy. 2013. Algal Biofuels. www.biofuels.energy.gov.

Utama, S. 2009. Memanen Bioetanol di Pabrik Terapung. Tabloid Agrina. Jakarta.

Vries dkk. 2010. Buku Panduan Energi Terbarukan. PNPM Mandiri. Jakarta.

Wawa, J. E. 2005. Pemerintah Provinsi Harus Segera Menyiapkan Lahan Pembibitan. www.kompas.com.

Winarno, F, G. 1996. Teknologi Pengolahan Rumput Laut. Pustaka Sinar Harapan. Jakarta.

Yunizal. 1999. Teknologi Ekstraksi Alginat dari Rumput Laut Coklat (Phaeophyceae). Instalasi Penelitian Perikanan Laut Slipi, Balai Penelitian Perikanan Laut, Pusat Penelitian dan Pengembangan Perikanan. Jakarta. 